\title{
Cooperation and Collaboration Impact on Policy Development: HIV/AIDS Policy in Latvia
}

\author{
Ieva Bikava, Ilga Kreituse \\ Riga Stradins University, Riga, Latvia
}

\begin{abstract}
This article describes a case study of trends of governance approach implementation in the health policy development and implementation process in Latvia, in the state in transition, or "new democracy". Latvia became an independent democratic state in 1991, regaining its freedom after being part of the Soviet Union for 50 years. As the three Baltic States (Latvia, Lithuania, and Estonia) had a common history and starting point in the health reform implementation, the data of Human Immunodeficiency Virus (HIV) incidence and implemented policy steps were analyzed and compared of all the three states. The research provides insight into the HIV/Acquired Immune Deficiency Syndrome (AIDS) situation in Latvia from the time when the first patient was diagnosed till nowadays, describing the initiatives that were implemented to combat the spread of HIV infection and analyze the impact of different stakeholders in the policy development and implementation process. Although the main reform implementation actors in Latvia were Non-Governmental Organizations (NGOs) or patient organizations by performing cooperation and collaboration with all the actors involved in the policy development and implementation process, more profound investigation reveals that major impact came from "old democracies", international and global organizations as well as from physicians and commercial powers by providing a suitable environment for the reform development.
\end{abstract}

Keywords: governance, Non-Governmental Organizations (NGOs), health policy

\section{Introduction}

The epidemic of Acquired Immune Deficiency Syndrome (AIDS) and the spread of Human Immunodeficiency Virus (HIV) infection are a worldwide problem for more than three decades, and according to the Joint United Nations Programme on HIV and AIDS (UNAIDS), the common goal for the whole world is to stop the AIDS epidemic by year 2030, by ensuring that everyone living with HIV has access to HIV treatment. The new formula or target that should be reached by 2020 is " $90-90-90$ ", meaning that by the end of year 2020: $90 \%$ of all people living with HIV will know their HIV status, $90 \%$ of all people with diagnosed HIV infection will receive sustained antiretroviral treatment (ART), and $90 \%$ of all people receiving ART will have viral suppression (UNAIDS, 2017).

HIV as an infectious disease has an impact on health and wellbeing of the whole society, and is not a national or even regional, but a global problem; so to combat the epidemic, activities have to be carried out globally. One of the indicators of the global significance of the HIV problem is establishment of the UNAIDS organization by the United Nations Economic and Social Council (ECOSOC) on 26 July, 1994 to undertake a

Ieva Bikava, Ph.D. student, Department of Political Science, Riga Stradins University, Riga, Latvia.

Ilga Kreituse, Ph.D., professor, Department of Political Science, Riga Stradins University, Riga, Latvia. 
joint and cosponsored program on HIV on the basis of co-ownership, collaboration, planning and execution, and an equitable sharing of responsibilities with six cosponsoring United Nations organizations. UNAIDS still remains the only cosponsored joint program of the United Nations system and provides all levels of inclusiveness, providing multi-stakeholder approach with member states, cosponsors and civil society, and specifically people living with and affected by $\mathrm{HIV}^{1}$.

To achieve the Goal 90-90-90 and combat the spread of HIV infection globally, all the member states should take actions and work in collaboration and cooperation with the civil sector and Non-Governmental Organizations (NGOs) on local levels providing good and smart governance.

Latvia is a state in transition or a "new democracy", located in the Baltic Region of Northern Europe. The state regained its freedom from the Soviet Union in year 1991, as did both the neighboring countries Estonia and Lithuania. Other countries that have borders with Latvia are Russia and Belarus. Latvia in year 2019 has $1,919,968$ inhabitants and its territory is $64,573 \mathrm{~km}^{2}$. Average life expectancy at birth for males is 70 years; for females is 79.6 years. The gross domestic product (GDP) in year 2018 was 29,523.664 million euros, per capita 15,328 euros, and per employee 32,796 euros. Total expenditure of government in year 2017 was 10,220.064 million euros and $37.806 \%$ of GDP, expenditure on health was 947.699 million euros or $3.506 \%$ of GDP or 9.273\% of total Government expenditure (CSB, 2019a; 2019b; 2019c; 2019d).

Since March 29, 2004, Latvia is a member of the North Atlantic Treaty Organization (NATO) and since May 1, 2004, it is a member state of the European Union. Although the healthcare policy is the national competency of every member state of the European Union, HIV as an infectious disease is an influential factor to public health, and that is a part of the whole European Region policy. As Latvia is a partner and member in several unions and associations, it has obligations to work in cooperation and collaboration and under the collective policy to achieve global targets.

The change that started in year 1991 by separating from the Union of Soviet Socialist Republics (USSR), initiated a global change in the way how health politics was organized: from centralized, planned economy health care system, to a new, comprehensive, and decentralized system. The implementation of new approaches in governing was stimulated by developed "old democracies" in other European countries, but hindered by the historical effects known as "path dependency" and "institutional inertia".

While in the "old democracies" in the middle of the 1990s, the second wave of governance-"Meta Governance" was reached, in the Baltic States, it was only a start of the first wave of governance-"Network Governance".

Shift from the old way of governing to a new approach, according to James A. Rhodes: "Governance signifies a change in the meaning of government, referring to new processes of governing; or changed conditions of the ordered rule; or new methods by which society is governed" (Rhodes, 2012, p. 33). The change implies not only a change in the processes and rules, but according to Levi-Faur, it also "includes a shift from politics to markets, from the community to markets, from politicians to experts, from political, economic, and social hierarchies to decentered markets, partnerships and networks" (Levi-Faur, 2012, p. 7).

Change in the processes and environment requires also

a paradigm shift from the old regulation by command and control to a regulatory governance model, signifying a collective intellectual and programmatic project for a new legal regime. New governance offers a vision of law and policy

${ }^{1}$ UNAIDS (Governance). About governance. Retrieved from https://www.unaids.org/en/whoweare/governance. 
that draws on the comparative strengths of both private and public stakeholders and highlights the multiple ways in which the various actors in society contribute to the acts of ordering social fields. (Lobel, 2012, p. 65)

All the previously mentioned changes lead to the question: How these changes impact and change the role of the state in the process of reform or in the political change development and implementation process? The answer, provided by Guy Peters is:

One can also conceptualize good governance as the existence of a state, operating alone or along with its partners that provide a wide range of services to the public. The logic is that the state should use its capacity to tax, spend, and regulate in order to improve the lives of citizens, a version of governance that clearly describes the welfare states of Europe. (Peters, 2012, p. 26)

Clarifying the meaning of governance in a health sector, according to the WHO definition "Governance is a political process that involves balancing and competing influences and demands" that is provided by "wide range of steering and rule-making related functions carried out by the government's decision-makers as they seek to achieve national health policy objectives" (WHO, 2019).

Narrowing the wide subject of health politics to HIV topic, the infectious disease that is not only a problem of the national, but also regional level, and which is influenced by a broad range of aspects, the role of cooperation and collaboration becomes even more significant and should be aimed to correspond to the WHO characteristics: "Beyond the formal health system, governance means collaborating with other sectors, including the private sector and civil society, to promote and maintain population health in a participatory and inclusive manner" and should be managed in that manner in either way-internally or locally as well as externally or globally (WHO, 2019).

\section{HIV/AIDS Patient in Latvia-25 Years Retrospective}

The first patient diagnosed with HIV in Latvia was in year 1987 and the HIV/AIDS Register was established in year 1994. According to data from the Register, on the 1st of July 2018, there were 5,500 patients in Latvia who were infected with HIV, but according to data from HIV specialists, the real figure of people infected with HIV in Latvia is for approximately one third higher (Latvijas Sabiedriskie Mediji [LSM], 2018).

According to the data from the Centre for Disease Prevention and Control of Latvia, in year 2018, newly diagnosed patients with HIV were 326 (221 male and 105 female). The distribution of transmission ways in year 2018 is as follows: The leading cause is heterosexual transmission (109), injection drugs (73), homosexual transmission (19), vertical transmission (5), and almost one-third of cases where the way of transmission was unknown (120). During the period of 1987-2018, patients diagnosed with HIV-7,669 (913 of which are dead) and patients diagnosed with AIDS-2,036 (1,121 of which are dead) (SPKC, 2019a; 2019b).

The spread of infection prevalence is variable over time-starting to rise from year 1997, reaching its peak in year 2001, significantly decreasing in year 2005, and still rising again nowadays. During the whole period, dominating group of the patients is male (see Figure 1). 


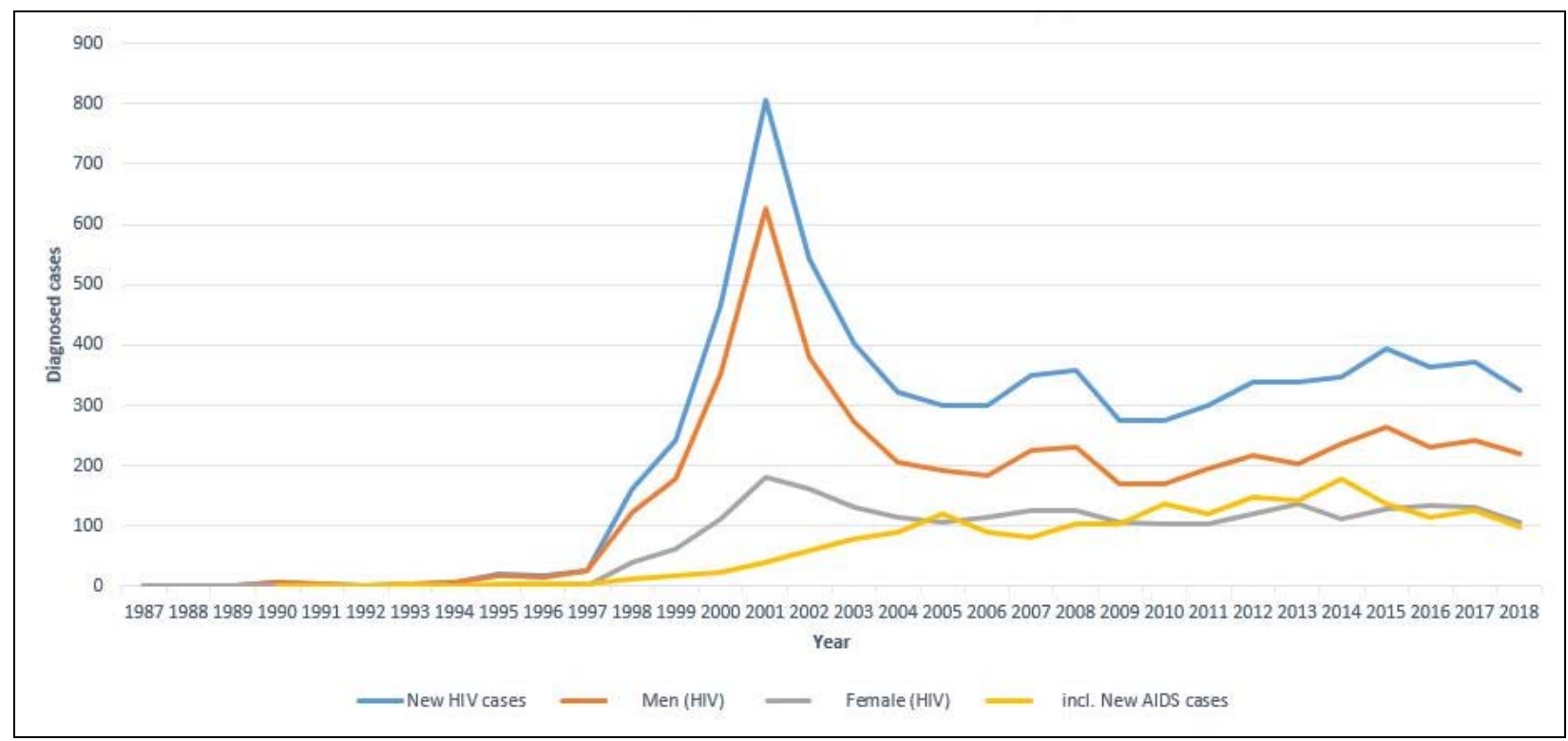

Figure 1. HIV/AIDS diagnosed cases in Latvia (Source: SPKC, 2019a; 2019b).

The way of transmission over time has significantly changed from homosexual transmission dominating at the start, to heterosexual transmission dominating at present; however, there is a significant part of patients with an unknown way of infection transition (see Figure 2).

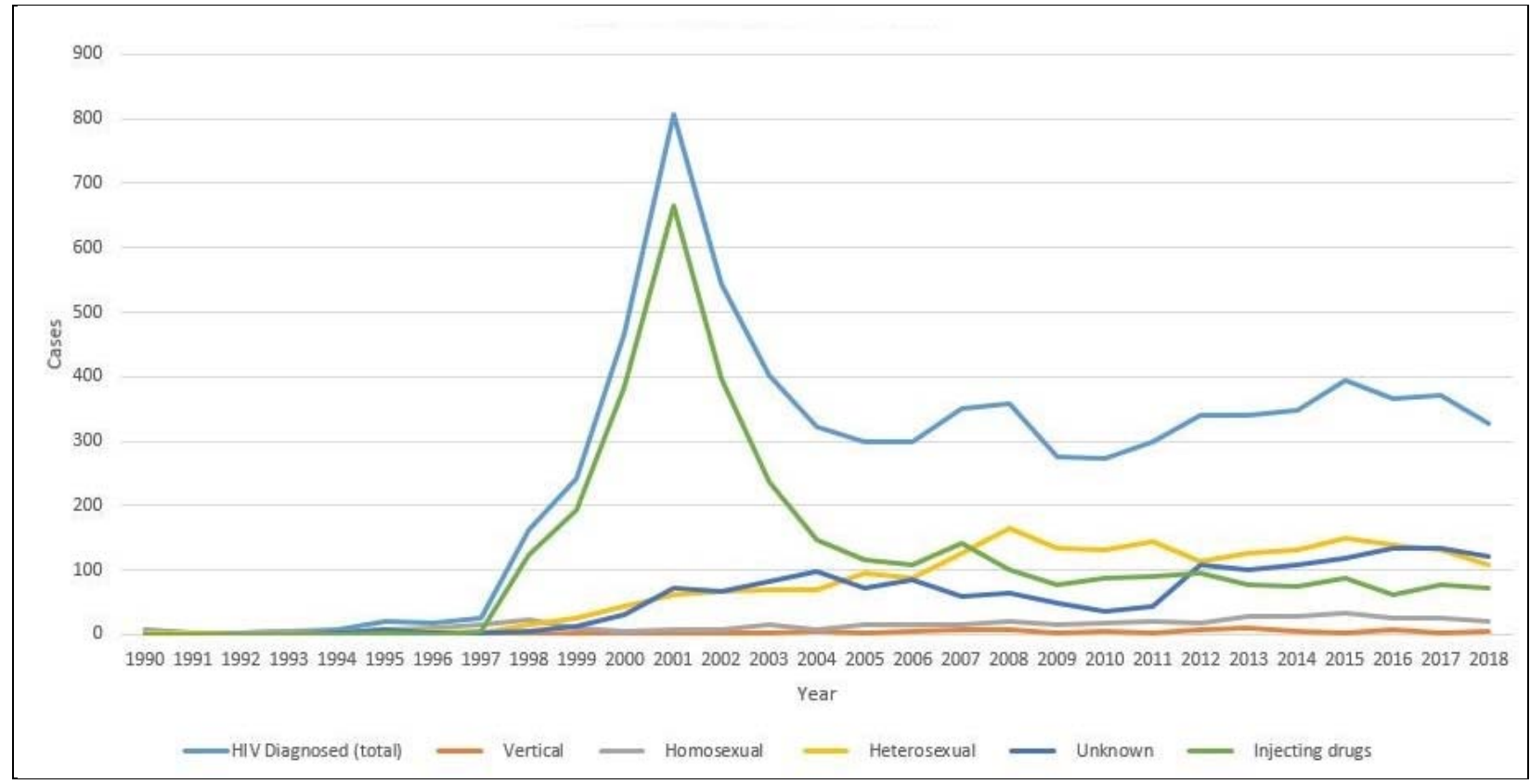

Figure 2. Way of HIV transition in diagnosed cases in Latvia (Source: SPKC, 2019a; 2019b).

As can be observed from these data until year 1995, the increase in the number of patients diagnosed with HIV was relatively low, that is, 10 newly diagnosed cases with the leading way of transmission-homosexual and diagnosed mainly in male.

The explosive increase in diagnosed cases was observed in year 2001, when the number of HIV diagnosed cases increased to 807 persons (626 male and 181 female) and the dominating way of transmission was 
injecting drugs. In the next period of years 2002-2005, the number of diagnosed cases falls significantly to 299 cases in year 2005, but still the main way of transition is drug injection. Only in year 2007, change in the way of infection transition is observable and dominating way becomes heterosexual.

Comparing the data of HIV incidence with the neighboring countries-Lithuania, Estonia, Belarus, and Russia, there is a noticeable relation during the period of years 1996-2017, when the data show that the epidemic began in neighboring countries: from Russia in the East (rate 40.35 in year 2000 and 59.44 in year 2001) and from Estonia in the North (rate 28.48 in year 2000 and 108.06 in year 2001), but staying relatively low in the South: Lithuania (rate 2.07 in year 2001 and peak of 11.44 in year 2002) with no significant impact on Belarus in the South-East. The epidemic started in the North with a dramatic impact on Estonia, presumably on the border with Russia (there is no public data available on the situation in Russia from year 2002 till year 2010) and then spreading down to Latvia and Lithuania (see Figure 3).

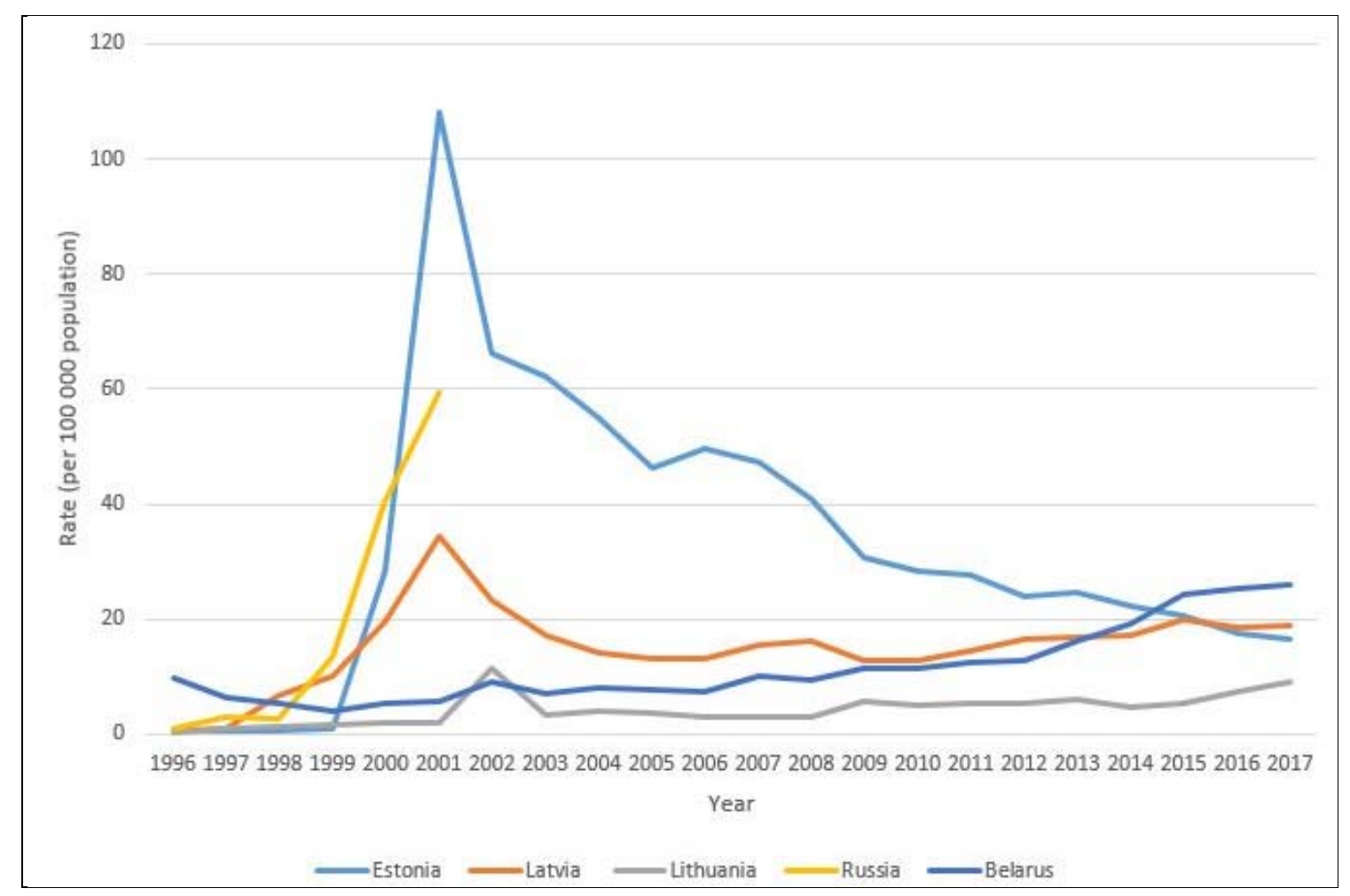

Figure 3. HIV incidence (Source: HIV/AIDS Surveillance in Europe, 2001; 2008; 2018).

According to the data from the research in Estonia, the HIV epidemic started in the community of injecting drug users; as shown from cross-sectoral bio-behavioral studies and data from needle and syringe exchange programs conducted in year 2005, majority of HIV cases in Estonia have been diagnosed in the capital city-Tallinn (32 cases per 100,000 in year 2005) and in Ida-Viirum county in the North-Eastern part on the border with Russia (76 cases per 100,000, in year 2005 [NIHD Estonia, 2016]).

The data about HIV incidence in the region as well as research in Estonia confirm that the HIV infection in this region started in Russia and afterwards spread through neighboring countries, thus once more confirming that infectious diseases are not only national, but also a regional problem and to overcome it, the activities have to be performed in cooperation and collaboration. 
Comparing data of AIDS incidence with the neighboring countries during the long-time period of years 1996-2017, Latvia was the country with the highest rate of cases almost for the whole period, when HIV was diagnosed at the AIDS phase (see Figure 4).

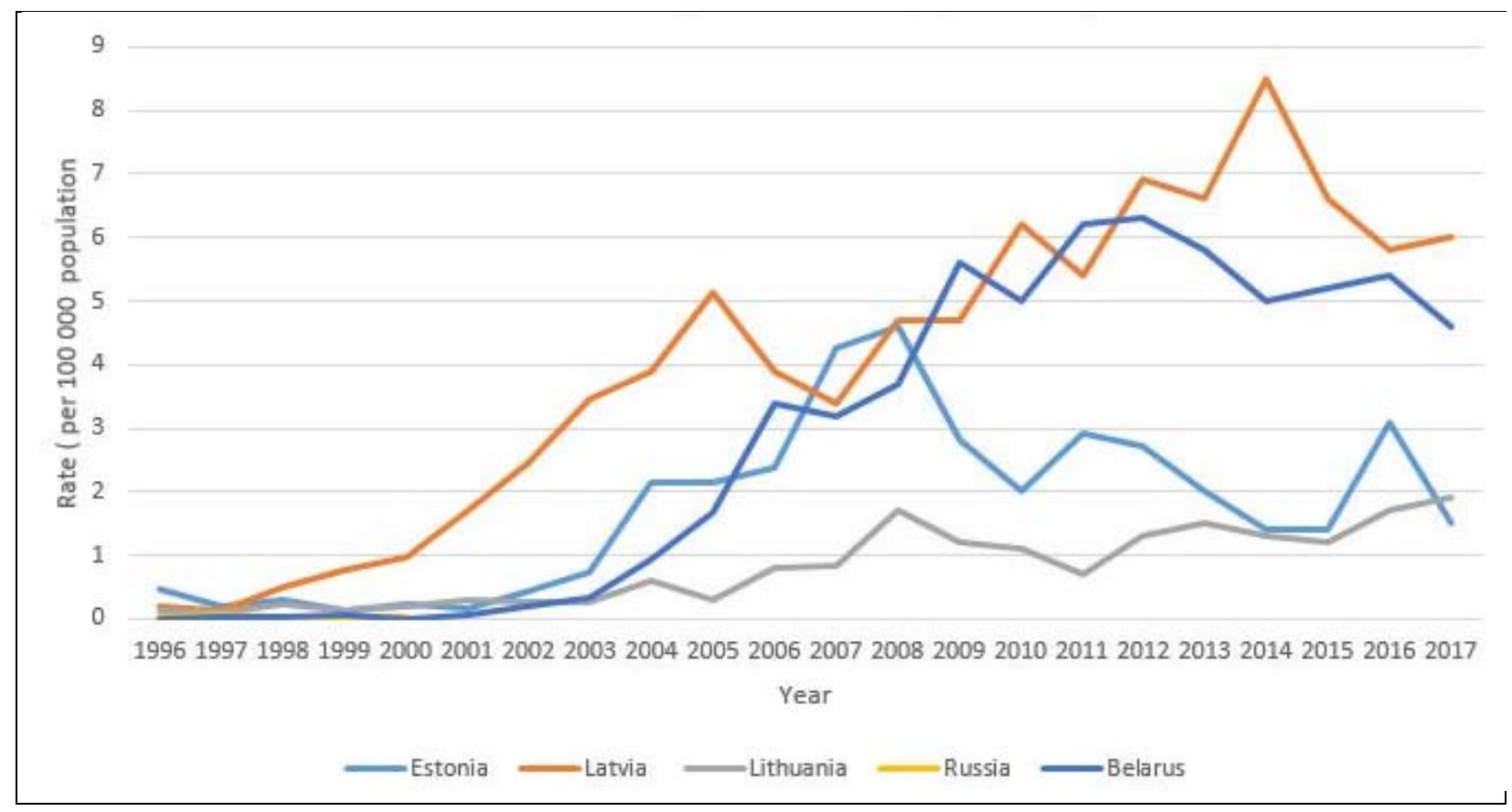

Figure 4. AIDS incidence (Source: HIV/AIDS Surveillance in Europe, 2001; 2008; 2018).

Despite the fact that the highest incidence of HIV was in Estonia reaching the rate of 108.06 cases while the highest rate in Latvia was three times lower (34.27), the highest rate of AIDS incidence was in Latvia, and is still the highest among neighboring countries. Those data of AIDS incidence lead to the conclusion that there is a lack of timely HIV diagnosis and treatment possibilities in Latvia.

In comparison with other European countries in year 2017 where the average rate of HIV diagnosed patients was 6.2 per 100,000, in Latvia the rate was three times higher, reaching 18.8 per 100,000 people. In Latvia, there is not only the highest rate of newly diagnosed HIV patients in Europe, but also the average rate of AIDS patients 6.0 per 100,000, while in Europe 0.7 per 100,000 (European Centre for Disease Prevention and Control [ECDC], 2018).

Research on HIV/AIDS policy development and implementation process in Latvia indicated that significant actors were Non-Governmental Organizations (NGOs), especially those who represented patients. The first NGO aimed to support persons with HIV/AIDS was established in year 1993, named Latvian for Support Group for People Living with HIV/AIDS (AGIHAS). Another NGO, established in year 2006, was "Apvieniba.HIV"- the association that is working to improve the quality of life of people infected with HIV, in all its aspects involving advocacy as well as other forms of support.

In year 2010, an international NGO "Baltic HIV Association" that united three Baltic States-Latvia, Lithuania, and Estonia was established. The NGO involves well-known specialists, former employees of United Nations Office on Drugs and Crime (UNODC), national AIDS center, and researchers.

The main activities performed by NGOs were more focused on the provision of expertise in the HIV field by submitting recommendations to the Ministry of Health and other organizations. All three NGOs are still 
actively working to protect the rights of the HIV/AIDS patients and to improve the quality of patients' life and access to healthcare.

One of the most significant factors for the HIV/AIDS patient treatment possibilities and to work on restricting the spread of infection in Latvia was due to the restrictions of possibilities to receive state-funded medication-Anti Retroviral Therapy (ART).

At the beginning, the ART was provided only to patients if their immunity level; it is the number of Cluster of Differentiation 4 (CD4) cells was below 200. Although the UNAIDS recommended to abolish any restrictions depending on the immunity level of CD4 cells on receiving ART already in year 2015, due to scarce funding resources, these changes in Latvia were implemented only at the end of year 2018. In comparison to other developed countries, the state provided funding to healthcare needs is lower than $4 \%$ of GDP (aiming to reach 4\% of GDP in 2020). The scarce resources impose limitations on possibilities to provide more funding to healthcare, especially for granting the funding to marginalized groups.

Since July 1, 2016, the ART was provided to patients in Latvia if their rate of CD4 cells was below level 350. Since January 1, 2018, if CD4 was below 500 and despite scarce resources and other obstacles, the goal was reached and since October 1, 2018, every patient diagnosed with HIV in Latvia can receive state-paid ART. How this was achieved is described in the section about NGO impact on policy development. In comparison with neighboring countries, in Estonia, restriction on CD4 count was abolished in 2016, in Lithuania in February 2018.

A significant factor that was highlighted in discussions with the patient organizations in Latvia is the lack of specialists available in regions. There is only one hospital in Latvia where HIV/AIDS patients can receive consultations and prescriptions for medicine. For patients living in further regions from the capital Riga, especially for those who do not own a car, it is an obstacle to be a sympathetic patient and to follow all the treatment recommendations. That is a "hot topic" in Latvia, not only for HIV patients, but also for C-hepatitis and patients of other diseases. That is related to an insufficient number of specialists available in regions as well as to patients specific population density - in Riga, the capital of Latvia where half of all the population of Latvia is living.

However, the most frightening factor for the HIV patient in Latvia is the high level of stigmatization and lack of knowledge about the disease and ways of its transmission in all parts of the society-also among medical specialists, especially the ones working in primary health care.

According to first available research on society attitude to HIV infected people in the Baltic States, from the survey performed in Lithuania in year 2003 on public opinion about vulnerable groups, there is a significant increase in tolerance towards the people with HIV during the time. In year 1990, 77.6 percent of questioned people admitted having no wish to live in a neighborhood with people infected with HIV, in year 2003, this percentage was only 49.3 or 1.5 times less (Lithuanian AIDs Centre, 2004).

The latest research on HIV Stigma index in the Baltic States was performed in Latvia in year 2018 by interviewing 409 HIV patients about their experience receiving health care services, attitude towards them in their workplaces and from their families, and friends. Research was also carried out on other aspects characterizing patients' quality of life, social status, and self-stigmatization. According to the research results, due to a very high level of stigmatization in the society, $75.8 \%$ of patients are hiding their HIV diagnosis from others, $24.1 \%$ has decided to obtain from various social events, and $15 \%$ are isolating themselves from their families and friends (LETA, 2019). 
Because of the HIV situation, most of the HIV patients feel various negative emotions: $50.5 \%$ feel ashamed, $47.2 \%$ feel guilty for having the HIV, $33.7 \%$ feel worthless, and $27.6 \%$ feel like being dirty (LETA, 2019). The same research on Stigma index was performed in Estonia, already in year 2010. According to data from research in Estonia: Over 60\% reported feeling guilty, 57\% blamed themselves, $42 \%$ felt ashamed, and over 33\% had low esteem (Estonian Network of People Living with HIV [ENPLHIV], 2012). Comparing results of the first Stigma index research in the Baltic States-performed in Estonia with the second research, made eight years later in Latvia, the level of stigma has decreased, but is still very high.

According to research results on social life activities in year 2018, 12.2\% of HIV patients in Latvia due to their HIV status decided not to have sex, $6.6 \%$ did not ask for medical help, 5.6\% were not looking for social help, $5.4 \%$ decided not to apply for work, and $38 \%$ of HIV patients had experienced discrimination from medical specialists or family. Discrimination has been also observed on behalf of primary care specialists-17.1\% of patients have experienced rumors from medical personnel, $8.2 \%$ received recommendations to discontinue their sexual life, and $6.7 \%$ noticed that information about their HIV status has been revealed to other persons without their permission. According to reproductive health research results, $6.6 \%$ of patients received recommendations not to have children and $15.8 \%$ females to interrupt their pregnancy, although using ART provide possibilities to give birth to healthy children (LETA, 2019).

In the circumstances, there is enormous stigmatization from the society as well as self-stigmatization, lacking information about treatment possibilities and on options on how to live a quality life and stay an active member of society, while facing obstacles and misunderstandings in communication with healthcare professionals, the patient who have been diagnosed with HIV feels confused, abandoned, scared, and determined.

During the last few years, a lot of initiatives to support and improve the lives of HIV patients were implemented. Apart from the change in the regulation of ART availability, a special national plan for HIV/AIDS and C-Hepatitis diagnostics and treatment has been developed and confirmed by the government at the end of year 2017, special programs of children nutrition have been implemented to support children born from HIV positive mothers, as well as a special program has been created to inform and support HIV patients.

Of course, the situation for a patient diagnosed with HIV has been significantly changed and improved in comparison with the recent past, but there is still a lot of work to do to improve the possibilities for HIV patients in Latvia, to lead a quality life and enjoy one's existence. In addition to current problems, new actual topics are developing - aging and HIV. That is a reality of today, as patients living with AIDS are becoming 70 and older, and have multi-morbidity.

\section{NGO Impact on Policy Development and Implementation}

To get an inside view and explore how changes in the policy were achieved, the research was made on HIV/AIDS policy development and implementation process in Latvia. According to the research, all the previously mentioned results and implemented political initiatives in HIV related topics in Latvia were driven mainly by activities carried out by Non-Governmental Organizations (NGOs), especially patient organizations, with the leading player NGO "AGIHAS". The activities that were carried out by this NGO had a significant impact on the society, the government and the Parliament, providing necessary pressure to the state institutions to make decisions and satisfy the demand of the society.

AGIHAS was established in year 1993 with the aim that still after more than 25 years is the same: 
The goal of the organization is to create throughout the region countries, life improvements and recognition of the rights of those affected by HIV/AIDS as well as to inform and educate the society, patients and those around them on the HIV infection, its risks and prevention tools, and finally increase adherence to HIV diagnostics, therapy and disease management. (AGIHAS, 2019)

The most significant competence of the association that unites HIV patients is, as mentioned by the chairman of the board: "AGIHAS knows how it is to live with HIV and how it really feels, unlike-others-who only try to imagine, how it could be to live as HIV positive". As the leaders of the NGO revealed, the success of the organization was not having some special strategy, long-middle and short term goals, neither plans nor projects, the whole 25 years, the organization was performing activities to combat the biggest problems that HIV patients have at that time.

The first wave of activities at the end of the 1990s and the start of the millennium were focused on the people who were drug users and persons in places of imprisonment, as those were the places were situation was really dramatic. According to statistics, at that time, the dominating group infected by the HIV was men and the dominating ways of transmission were injecting drugs. The spread of infection among drug users rose dramatically starting from year 1997 when there were only five cases, reaching the top in year 2001 when infection was gained by intravenous drug usage in 666 cases (SPKC, 2019a; 2019b).

Significant projects carried out by several NGOs (not only those-dedicated to HIV patients, but also others like "Red Cross") with the aim to fight the spread of infection among intravenous drug users and to create special places where drug users could exchange used syringe and get sterile ones for free. As was mentioned in the articles, those places became very popular for drug users and those activities lead to a significant decrease of infection spread.

Another smaller, but also an important activity was a project on elementary things-to give information to most vulnerable and hard to reach people by providing flyers and booklets about the infection transmission ways and giving free condoms-mainly in the places were drug users came to change syringes. Those projects of providing free exchange of used syringes are still active today and supported by many municipalities and now also partially funded by the state, as those projects exposed significant results.

Similar activities were already earlier implemented in Estonia. HIV testing and counseling services to commercial sex workers have been provided since year 1994, needle and syringe exchange programs were initiated in year 1997 (Laisaar, Avi, DeHovitz, \& Uuskula, 2011).

In Lithuania, in year 1997, an anonymous counselling room for drug users was established offering needle exchange services that was sponsored by self-government of Klaipeda municipality and was the first of its kind in the Baltics. It took up the activities of needle and syringe exchange, condom distribution, dissemination of educational publications, and consulting on safer drug use and sexual behavior (Lithuanian AIDs Centre, 2004).

Another NGO working mainly on topics about sexual education in adolescent groups in Latvia is "Papardes zieds". It also carried out projects to educate youth about the HIV infection and safe sex as well as about other topics related to reproductive health. Those projects were not directly related to HIV infection, but knowledge about safe sex was also important to youth. Although those projects were successful, and even for some years, there was a special subject "health education" included in the school programs, after several years discussions arose in the society about the virtue and those topics were again excluded from the school programs. But there are still debates in the society on the topic, since after the changes made to raise a more virtue youth, the number of undesirable pregnancy cases in adolescence group increased. 
When the first target audience-drug users were covered with the solution how to restrict infection among them, the second target group was identified at the start of the millennium was MSM (men having sex with men). That mostly happened in the places of imprisonment where those activities in most cases were not vulnerable. The projects carried out there were the same, providing flyers and booklets about the ways of infection transmission and by giving free condoms.

When the first activities aimed to educate the society and limit the spread of infection were implemented and ran smoothly with great results, the next steps performed by NGOs were to consolidate community-the persons infected with HIV that was stigmatized groups and felled as pariahs. The NGOs created groups for self-support, in the places where HIV patients could come to talk to each other and feel like a social being. As most of the patients were not having any understanding or compassion and felt isolated by family, friends, and relatives, those became places where they could be themselves without wearing a mask. Even after many years and changes that have happened in the way how society refers to HIV patients, those support groups are still popular and required by the patients, especially after their first reaction-resistance phase and anger are gone, and the phase of acceptance of the state has set in and the patient is looking for information on how to live his life further.

The idea of support groups, especially for patients who are recently diagnosed, was to help those patients to understand what the next steps are to be taken after the express test indicates that patient can be HIV positive. Support group provides persons who lead this new patient through the health care system, educate about how to live with HIV and how properly intake medicine, when and what tests should be made, monitor patients, assist, and support the patient. Those activities should provide increase in number of patients that are actively participating in the treatment process-use ART, regularly made tests and visits HIV specialist. After two years experience, when NGO came to the Ministry of Health of Latvia, and provided all the information-detailed reports on the program, activities and achieved results, the program was approved to be continued and funded by the state; starting from April 2019, this assistance program is a part of the state-run program and will be provided in even more places than before.

The next step taken by NGOs was intended to provide better opportunities for children born from the mothers having HIV. As one of the ways of infection transmission is breastfeeding, the idea was to provide all those newborns with artificial nutrition. The project was developed in cooperation with the leading hospital in the capital of Latvia, Riga Maternity Hospital. In the first year, the nutrition was provided only in this one, the leading hospital; in the second year, having great program results and a lot of positive feedback, the sponsors of the project were ready to provide more funding and provide program also to all other hospitals were HIV positive mothers gave birth to babies which were supplied by nutrition instead of breath milk. After one and a half year, with reports on all of the results of the project-criterions, expenses, and outcomes presented to the Ministry of Health, as it was the period announces as dedicated to "Maternal and child health" and there were funding available from European Funds run under this program-this initiative also become state-provided project since July 2018 and is still running with great results. So, it is another example how the project developed and carried out by an NGO and funded by a non-state budget, with good results and being economically and socially effective and efficient, can become state-funded. Those few examples not only show how NGO initiatives can become state projects, but also demonstrate possibilities, knowledge, and expertise as well as leadership skills that NGOs have, but the state institutions in most cases did not have.

However, the most valuable goal that has been reached as evaluated from both patient organizations and specialists was the development of "Action Plan for the Preventive of HIV, Sexually transmitted infections and 
Hepatitis B and C for The 2018-2020 year" that was approved by the Cabinet of Ministers of Latvia on October 31, 2017.

All those achievements were reached by activities performed by NGOs, which were using all the tools and approaches that are described in Interest Group theory and Lobbying theory. For example, removal of the threshold was reached exerting pressure on decision-makers by organizing a campaign and publicly claiming Latvia to be the last state in the European Union having the limitation on access to ART for HIV patients as well as having a public discussion in the Ministry of Health and inviting UNAIDS ambassador to visit Latvia (the visit was organized by the NGO "AGIHAS") to publicly speak and disgrace Latvia on this topic.

Another initiative carried out by NGO "AGIHAS" in collaboration with other associations for several years is the conferences on international Worlds AIDS Day on December 1. These activities are great reminders of the existence of HIV/AIDS patients and impact of this infectious disease on the society, decision-makers included.

According to action plan development, the great result was achieved working hand-in-hand with all the groups related to this topic: medical professional associations, patient NGOs, pharmacy, hospitals, and of course, the government institutions. According to the information from interviews, the process of action plan development was heavy and took quite a long time and countless hours spent in the search for compromises and best possible solution, acceptable by the majority of involved stakeholders. Although no one was completely satisfied with the result, in spite of scarce resources of funding, insufficient number of available specialists and the overall situation in healthcare sector in Latvia, the developed and approved action plan was a great achievement.

Although when discussing activities and achieved results, the most significant actors are medical specialists, which knowledge, competence, and performing diagnosis and treatment, as well as patient organizations, of course, there are also some other power-players in the shadows or the pharmacy. Especially in the situation in Latvia, there are no special government funds provided to NGOs, and according to research results, the main supporters for NGOs, especially patient NGOs, are the pharmacy. In Latvia, there is a special regulation on activities that can be supported by drug manufacturers and that are prohibited, but the support of drug manufacturers, especially the global world known pharma companies have a significant role in supporting those NGOs.

Another factor worth mentioning that provided possibilities for NGOs to achieve such great results was funding that was available in different cross-border programs as well as European Union Funds. NGOs were actively participating in program contests with their projects and significant part of NGOs projects were established by those foreign funds. There was also funding from local organizations that supported meaningful projects carried out by NGOs, for example, program on newborn nutrition was sponsored by the donations from two local organizations.

\section{Conclusions}

The research revealed that Non-Governmental Organizations (NGOs) and other interest groups have a significant impact on the society in the development towards a better democracy, by providing protection of the interests of marginal groups, especially in the case when those marginal groups are unwelcomed and stigmatized by the society.

Research results confirm the widespread findings in the governance theory in "new democracies" were an active participatory society is developing, as written by Frank Fischer: 
In many of the newly created participatory space activists have assisted excluded people-such as poor, women, AIDS victims, and the disabled-in developing a collective presence that has permitted them to speak for themselves. Through such efforts, activists and their citizen groups have in many cases succeeded in influencing the policies of mainstream institutions. (Fisher, 2012, p. 467)

Another finding from the research was the lessons learned that good initiative with well-defined and achieved results that are reached by providing pilot projects and run by NGO can become a part of the state-funded and implemented policy afterwards. That can be explained by the knowledge, expertise, practice, and courage to deal with the risks and failures that interest groups or NGOs can afford, but the state lack, or cannot.

According to the new approach of governing-governance, research on HIV/AIDS policy development, and implementation revealed that in Latvia, the "new democracy" state, there is a place for the society and the private sector to have an impact on the policy development and implementation, but unfortunately the good governance practice is not yet observed, since the state is not the leading actor in the policy development. In this case, the leading actor was the patients NGO, having enormous support from the medical service providers-physicians and pharmacies.

Looking superficially at events described in this research report, it can be concluded, that the major and most visible actor in the change implementation were the patients organizations. However, according to theoretical findings by Yael Yishai (2012, p. 535),

Patients influence is augmented when officials wish to introduce change and use health groups to support them in the face of professional opposition. Occasionally, patients are also drawn into partnerships with physicians to impede bureaucratic initiatives. Even under these circumstances patients do not exert influence on the policy process, but serve as cogs in the machine.

Another aspect that is mentioned in the literature and was observable also in the case study in Latvia was as per Yishai "Health groups often depend on pharmaceutical companies for their organizational resources. The lack of independence and competition for funding also divides the patients' movement, ultimately wreaking its impact and undermining its representation on a national level" (Yishai, 2012, p. 535).

Although according to theory, patient organizations are not recognized as powerful actors, in the case report on HIV/AIDS policy in Latvia, patient organizations were the leaders, who actively initiated and tirelessly maintained cooperation and collaboration with all the stakeholders. According to interviews and public opinion on possibilities of NGOs, to have an impact on institutions as well as the trust in democracy and power to influence some processes is very low and is correlated to previous achievements and long-term recognition of the NGO. As the chairman of the association AGIHAS mentioned, the organization has become an actor who is invited in public decision making and collaboration with institutions only in the last few years, and not like before when for about 20 years they were not welcomed in the policy development process.

A significant aspect that was observed during the research was the impact of other powerful players abroad. The most significant impact on decision-making arena environment was provided by the neighboring countries as well as international and global organizations. The new approach of governance provides that there is a developed civil society that supports and gives opportunities to interest group and NGO development. Therefore, another significant aspect of international institutionalism should be mentioned-the development of the civil society, which started in Latvia in year 2005, and the program provided to develop a powerful civil society was funded by the European Union and other foreign funding programs. So, we can conclude that there 
is a significant impact of "old democracies" in "new democracies" in providing the way to new style of society governing-new governance approach.

\section{References}

Atbalsta Grupa Inficētajiem ar HIV un AIDS Slimniekiem (AGIHAS). (2019). AGIHAS-Support group for people living with HIV/AIDS. Retrieved from http://agihas.lv/eng/

Central Statistical Bureau (CSB). (2019a). Usually resident population in statistical regions at the beginning of 2019. Retrieved from https://data1.csb.gov.lv/pxweb/en/iedz/iedz_riga/RIG010.px/table/tableViewLayout1/

CSB. (2019b). Life expectancy: Average life expectancy at birth in 2018. Retrieved from https://data1.csb.gov.lv/pxweb/en/iedz/ iedz_muza_ilg/PMG010.px/table/tableViewLayout1/

CSB. (2019c). Total gross domestic product in 2018: Annual data. Retrieved from https://data1.csb.gov.lv/pxweb/en/ekfin/ekfin _ikp_IKP_ikgad/IKG10_010.px/table/tableViewLayout1/

CSB. (2019d). Expenditures of general government by function by sub-sectors. Retrieved from https://data1.csb.gov.lv/pxweb/en/ ekfin/ekfin_valdfin_ikgad/VFG040.px/table/tableViewLayout1/

Estonian Network of People Living with HIV (ENPLHIV). (2012). The people living with HIV stigma index Estonia. Retrieved from http://www.stigmaindex.org/estonia

European Centre for Disease Prevention and Control (ECDC). (2018). HIV/AIDS surveillance in Europe 2018-2017 data. Retrieved from http://www.ecdc.europa.eu/sites/portal/files/documents/hiv-aids-surveillance-europe-2018.pdf

Fisher, F. (Ed.). (2012). Participatory governance: From theory to practice. In D. Levi-Faur (Ed.), Oxford handbook of governance (pp. 457-471). Oxford: Oxford University Press.

HIV/AIDS Surveillance in Europe. (2001). European Centre for the Epidemiological Monitoring of AIDS (EuroHiv). Retrieved from https://www.who.int/hiv/strategic/pubeurohiv66/en/

HIV/AIDS Surveillance in Europe. (2008). European Centre for Disease Prevention and Control. Retrieved from https://ecdc.europa.eu/ sites/portal/files/media/en/publications/Publications/0912_SUR_HIV_AIDS_surveillance_in_Europe.pdf

HIV/AIDS Surveillance in Europe. (2018). European Centre for Disease Prevention and Control. Retrieved from https://ecdc.europa.eu/en/publications-data/hivaids-surveillance-europe-2018-2017-data

Laisaar, K. T., Avi, R., DeHovitz, J., \& Uuskula, A. (2011). Estonia at the threshold of the fourth decade of the aids era in Europe. Aids Research and Human Retroviruses, 27(8). Retrieved from https://www.liebertpub.com/doi/abs/10.1089/aid.2010.0223

LETA. (2019). Edijs Pālens/LETA. Latvijā 38\% HIV inficēto piedzīvojuši diskrimināciju no gimenes un mediķiem (38\% of people infected with HIV have experienced discrimination from family and medical specialists). Retrieved from https://www.apollo.lv/6680279/latvija-38-hiv-inficeto-piedzivojusi-diskriminaciju-no-gimenes-un-medikiem

Levi-Faur, D. (2012). From "big government" to "big governance". In D. Levi-Faur (Ed.), Oxford handbook of governance (pp. 3-18). Oxford: Oxford University Press.

Lithuanian AIDS Centre. (2004). Lithuanian response to HIV/AIDS—First 15 years. Retrieved from http://www.sauliuscaplinskas. lt/books/15\%20years\%20with\%20aids.pdf

Lobel, O. (2012). New governance as regulatory framework. In D. Levi-Faur (Ed.), Oxford handbook of governance (pp. 65-81). Oxford: Oxford University Press.

Latvijas Sabiedriskie Mediji (LSM). (2018). HIV inficēto skaits Latvijā varētu būt par trešdaļu lielāks, nekā uzrāda oficiālie dati (The number of people living with HIV in Latvia could be one-third higher than oficial data indicates). Retrieved from https://www.lsm.lv/raksts/zinas/latvija/hiv-inficeto-skaits-latvija-varetu-but-par-tresdalu-lielaks-neka-uzrada-oficialie-dati.a2 96562/

National Institute for Health Development (NIHD) Estonia. (2016). HIV in Estonia: Situation, prevention, treatment and care. Narrative Report for Global AIDS Response Progress Reporting 2016. Retrieved from https://www.unaids.org/en/file/ 110927/download?token=hfImcvDw

Peters, B. G. (2012). Governance as political theory. In D. Levi-Faur (Ed.), Oxford handbook of governance (pp. 19-32). Oxford: Oxford University Press.

Rhodes, R. A. W. (2012). Waves of governance. In D. Levi-Faur (Ed.), Oxford handbook of governance (pp. 33-48). Oxford: Oxford University Press.

SlimĪBu Profilakses un kontroles Centrs (SPKC). (2019a). HIV/AIDS Statistics. Retrieved from https://www.spkc.gov.lv/lv/ statistika-un-petijumi/infekcijas-slimibas/datu-vizualizacija/hivaids 
SPKC. (2019b). Reports on selected infection and parasitic diseases. Retrieved from https://www.spkc.gov.lv/lv/statistika-unpetijumi/infekcijas-slimibas/valsts-statistikas-parskati/statistikas-parskati

Statistics Estonia. (n.d.). PH193: Incidence of selected registered infection diseases by infectious disease. Retrieved from http://pub.stat.ee/px-web.2001/dialog/Saveshow.asp

The Joint United Nations Programme on HIV and AIDS (UNAIDS). (2017). What we do. 90-90-90: Treatment for all. Retrieved from https://www.unaids.org/en/resources/909090

World Health Organization (WHO). (2019). Governance: Health systems. Retrieved from https://www.who.int/healthsystems/ topics/stewardship/en/

Yishai, Y. (2012). Participatory governance in public health: Choice, but no voice. In D. Levi-Faur (Ed.), Oxford handbook of governance (pp. 527-539). Oxford: Oxford University Press. 